\title{
Case Study on Incentive Mechanism of Energy Efficiency Retrofit in Coal-Fueled Power Plant in China
}

\author{
Donghai Yuan, ${ }^{1,2}$ Xujing Guo, ${ }^{3}$ Yuan Cao, ${ }^{2}$ Liansheng He, ${ }^{4}$ Jinggang Wang, ${ }^{5}$ Beidou Xi, ${ }^{4}$ \\ Junqi Li, ${ }^{1}$ Wenlin Ma, ${ }^{2}$ and Mingshun Zhang ${ }^{2}$ \\ ${ }^{1}$ Key Laboratory of Urban Stormwater System and Water Environment, Ministry of Education, \\ Beijing University of Civil Engineering and Architecture, Beijing 100044, China \\ ${ }^{2}$ Beijing Climate Change Response Research and Education Center, Beijing University of Civil Engineering and Architecture, \\ Beijing 100044, China \\ ${ }^{3}$ Key Laboratory of Development and Application of Rural Renewable Energy, Biogas Scientific Research Institute of \\ the Ministry of Agriculture, Chengdu 610041, China \\ ${ }^{4}$ Water Environment System Project Laboratory, Chinese Research Academy of Environmental Sciences, Beijing 100012, China \\ ${ }^{5}$ Department of Environmental Science and Engineering, Beijing University of Chemical Technology, Beijing 100029, China
}

Correspondence should be addressed to Donghai Yuan, yuansy79@yahoo.com.cn

Received 6 September 2012; Accepted 31 October 2012

Academic Editors: B. Chen, Z.-M. Chen, and H.-S. Tang

Copyright (c) 2012 Donghai Yuan et al. This is an open access article distributed under the Creative Commons Attribution License, which permits unrestricted use, distribution, and reproduction in any medium, provided the original work is properly cited.

\begin{abstract}
An ordinary steam turbine retrofit project is selected as a case study; through the retrofit, the project activities will generate emission reductions within the power grid for about $92,463 \mathrm{tCO}_{2} \mathrm{e}$ per annum. The internal rate of return (IRR) of the project is only $-0.41 \%$ without the revenue of carbon credits, for example, CERs, which is much lower than the benchmark value of $8 \%$. Only when the unit price of carbon credit reaches $125 \mathrm{CNY} / \mathrm{tCO}$, the IRR could reach the benchmark and an effective carbon tax needs to increase the price of carbon to $243 \mathrm{CNY} /$ tce in order to make the project financially feasible. Design of incentive mechanism will help these low efficiency enterprises improve efficiency and reduce $\mathrm{CO}_{2}$ emissions, which can provide the power plants sufficient incentive to implement energy efficiency retrofit project in existing coal-fuel power generation-units, and we hope it will make a good demonstration for the other low efficiency coal-fueled power generation units in China.
\end{abstract}

\section{Introduction}

With the rapid development of industrialization and urbanization, the global climate-change issue has become an important factor to affect the world economic order, political regime and international relations, as well as to determine the key of the world's energy future [1,2]. Global climate change is closely related to energy, a variety of greenhouse gases (GHG) that cause climate change. Carbon dioxide $\left(\mathrm{CO}_{2}\right)$ contribution rate is more than $50 \%$, and $70 \%$ of human activities' $\mathrm{CO}_{2}$ emissions are from the burning of fossil fuels [3]. At present, China is one of the countries with the most $\mathrm{CO}_{2}$ emissions in the word, and $\mathrm{CO}_{2}$ emissions are still growing rapidly. The main reasons for $\mathrm{CO}_{2}$ emissions of China are as follow: (1) The existing energy resource characteristics of primary energy consumption are dominated by coal, and thermal power accounts for about $70 \%$ of the total power generation; (2) the rate of energyintensive industries and products is high [4].

In the 12th Five-Year Plan, China has shown its intention to shift from a policy of maximizing growth to balance growth with social harmony and environmental sustainability [5]. But the dominant position of coal in the energy consumption will continue in a long period; by 2020, the GDP goal is quadrupling, and then the total installed capacity will reach 900-950 million kilowatts, generating capacity will reach 4.2 trillion $\mathrm{kWh}$, of which thermal power installed capacity still contains about $70 \%$. How to coordinate the relationship between the rapid development with $\mathrm{CO}_{2}$ emissions is a severe challenge for the power industry.

Today, there are lots of low efficiency power plants in China, which is urgent to implement the steam turbine 
retrofit, and these power plants have the great potential to reduce $\mathrm{CO}_{2}$ emissions. Because the development among different regions and industries in China is very uneven, the enterprises cannot afford the high cost of the steam turbine retrofit by themselves [6]. The introduction of an incentive mechanism to help these low efficiency enterprises to improve efficiency and reduce $\mathrm{CO}_{2}$ emissions has been practically significant [7]. In this study, a steam turbine retrofit project in China is selected for a case study to find an effective GHG emission reduction mechanism for this project type, which can provide the power plants sufficient incentive to implement energy efficiency retrofit project in existing coal fuel-power generation-units, and we want to make a good demonstration for the other low efficiency coalfuel power generation-units in China.

\section{Description of the Project Activity}

2.1. Site Description. Panshan Power Plant is located in the southeast of the Ji County, Tianjin City $\left(117^{\circ} 16^{\prime} 58^{\prime \prime} \mathrm{E}\right.$, $\left.39^{\circ} 59^{\prime} 26^{\prime \prime} \mathrm{N}\right)$. The mean annual temperature in Ji County is $10-11^{\circ} \mathrm{C}$, and the mean annual precipitation is approximately $700 \mathrm{~mm}$, of which three-quarters are distributed from July to September. Figure 1 is the location of Panshan Power Plant.

2.2. Description of the Project. Steam Turbine Retrofit Project of Tianjin Panshan Power Plant (hereafter refers to as the project) involves retrofitting supercritical steam turbine. The steam turbine with rated power of $500 \mathrm{MW}$ (hereafter refers to as PAT, project activity turbine), which was designed in the early 1970s and introduced from Russia, has been put into commercial operation since April 16th 1996. The technical lifetime of the power unit is 24 years. Designed as a super critical turbine set, the technological level of the PAT is relatively higher than the subcritical turbine sets that are commonly used and regarded as a good practice currently in current China. So up to 2009 (the year of retrofit action), the remaining life is 11 years, more than 8 years. The principal specifications of the steam turbine are shown below (Table 1).

The main target of the project is retrofitting the low pressure cylinder to reduce the coal consumption of the power generation, in particular, by promoting the performance of the low pressure cylinder. The components, including rotor, blades, diaphragm and its set, inner cylinder, and shaft butt seal of the low pressure cylinder, are retrofitted. Steam seal installed in the surrounding bend of the first stage of highpressure cylinder, steam seal of each turbine stage, and shaft butt seal of high-cylinder and medium-cylinder will also be altered (Figure 2).

The current practice with low efficiency would be continued in the absence of the proposed project. By adopting retrofit measures, the proposed project will not only reduce GHG emissions, but also contributes to sustainable development for local communities by the means of: (1) reducing the emissions of $\mathrm{SO}_{2}, \mathrm{NO}_{x}$, and coal ash due to the reduction of standard coal consumption; (2) improving the energy efficiency of power plant and promoting development

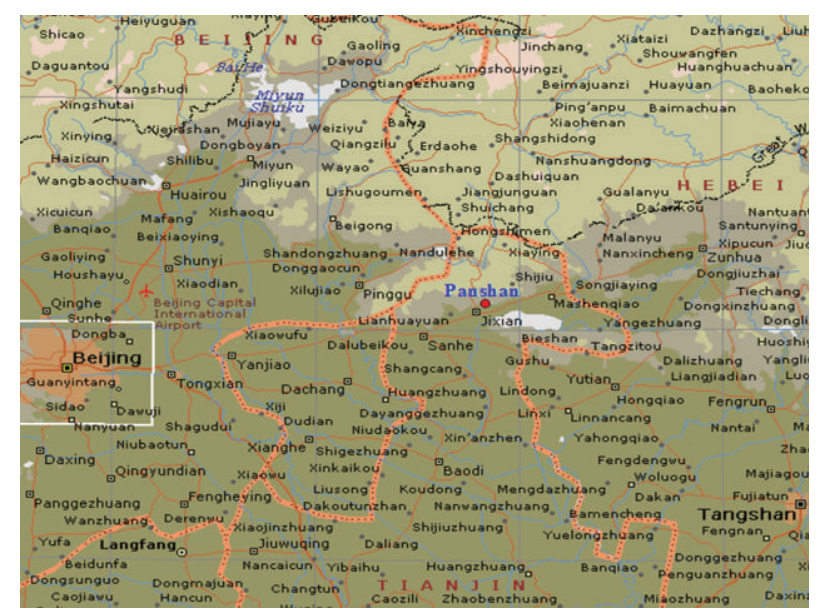

FIgUre 1: The map of the project location-Panshan Power Plant.

of manufacturing industry. The project is expected to give a lead on turbine retrofit of supercritical power plants in China.

\section{Performance Assessment}

3.1. Emission Reductions. To evaluate the effect of GHG emission reduction by the project with a quantitative way, the approved CDM methodology AM0062 in Unit Nation Framework Convention on Climate Change (UNFCCC) is applied to this study on the project in the following steps: calculate the baseline emissions, the project emissions, and the emission reductions [8].

3.1.1. Calculate the Baseline Emissions. (1) Determine baseline emission for the scenario of project electricity generation. Electricity generation in the project power plant will displace in the baseline scenario less efficient electricity generation in the project plant and can, in addition, displace electricity to the grid, if the quantity of electricity generation is increased as a result of the project. The calculation of baseline emissions is therefore based on different emission factors for different quantities of electricity generated. In China the annual power generation is determined by the annual dispatch order from grid company where the PAT connects to, thus it is assumed that annual power generation dispatch will be according to the original capacity of PAT. In this case, the annual power generation after retrofit unlikely exceeds the historical average level. Therefore the emission reduction is only relevant to the efficiencies of PAT before and after the retrofit.

To evaluate the emission reduction due to the retrofit, the follow case from AM0062 [9] is selected in a future analysis: the quantity of electricity generated in the project turbine (EGPJ,y) is lower or the same as the historic average annual generation level $\left(\mathrm{EG}_{\mathrm{AVR}}\right)$. Baseline emissions are calculated as:

$$
\mathrm{BE}_{\mathrm{y}}=\mathrm{EG}_{\mathrm{PJ}, \mathrm{y}} * \mathrm{EF}_{\mathrm{BL}, \mathrm{y}} \text {, }
$$




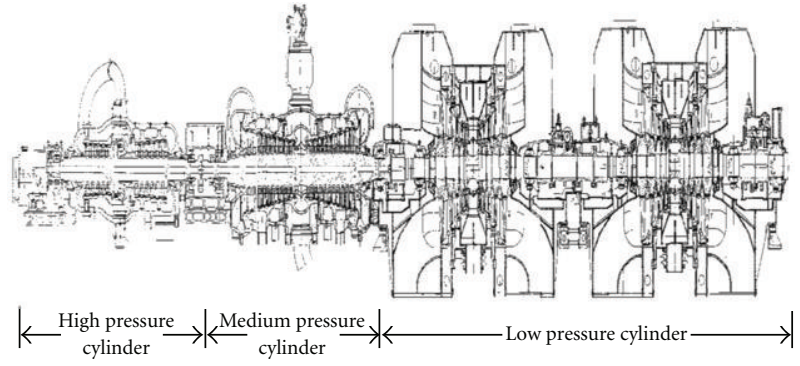

FIgURE 2: Profile of turbine.

TABLE 1: The principal specifications of the steam turbine.

\begin{tabular}{ll}
\hline Item & Designed value \\
\hline Manufacturer & $\begin{array}{l}\text { Leningrad metal factory of Russia } \\
\text { (designed in the beginning of 1970s) } \\
\text { Supercritical, once reheated, single } \\
\text { shaft, } 4 \text { cylinder and } 4 \text { steam exhaust, } \\
\text { condensing turbine }\end{array}$ \\
Type of turbine & $500 \mathrm{MW}$ \\
Rated power & $1528.8 \mathrm{t} / \mathrm{h}$ \\
Rated main steam flow & $23.54 \mathrm{MPa}$ \\
Main steam pressure & $540^{\circ} \mathrm{C}$ \\
Main steam temperature & $3.51 \mathrm{MPa}$ \\
Reheated steam pressure & \\
Reheated steam & $540^{\circ} \mathrm{C}$ \\
temperature & $4.27 / 5.44 \mathrm{kPa}$ \\
Exhausted steam pressure & Number of blade stage \\
Net heat rate & 54 \\
Lifetime & $8146 \mathrm{~kJ} / \mathrm{kWh}$ \\
\hline
\end{tabular}

where $\mathrm{BE}_{\mathrm{y}}=$ baseline emissions in year " $\mathrm{y}$ " $\left(\mathrm{tCO}_{2} / \mathrm{yr}\right)$, $\mathrm{EG}_{\mathrm{PJ}, \mathrm{y}}=$ quantity of electricity supplied by the project turbine to the grid in year " $y$ " $(\mathrm{MWh} / \mathrm{yr})$, adjusted for changes in efficiency, $\mathrm{EF}_{\mathrm{BL}, \mathrm{y}}=$ baseline emission factor of the project turbine in year y $\left(\mathrm{tCO}_{2} / \mathrm{MWh}\right)$.

(2) Determine Baseline Emission factor. The project turbine is steam turbine and the fuel is fired in a boiler, so its emission factor is calculated as follows [10]:

$$
\mathrm{EF}_{\mathrm{BL}, \mathrm{y}}=\frac{3.6}{1000} \times \frac{\mathrm{EF}_{\mathrm{FF}, \mathrm{BL}} \times \mathrm{FC}_{\mathrm{PJ}, \mathrm{y}} \times \mathrm{NCV}_{\mathrm{FF}, \mathrm{PJ}}}{\eta_{\mathrm{BL}, \mathrm{y}} \times \mathrm{HI}_{\mathrm{PJ}, \mathrm{y}}},
$$

where $\mathrm{EF}_{\mathrm{BL}, \mathrm{y}}=$ baseline emission factor of the Project turbine in year "y" $\left(\mathrm{tCO}_{2} / \mathrm{MWh}\right), \mathrm{EF}_{\mathrm{FF}, \mathrm{BL}}=\mathrm{CO}_{2}$ emission factor of the fossil fuel used in the Project turbine prior to the implementation of the Project $\left(\mathrm{tCO}_{2} / \mathrm{TJ}\right), \mathrm{NCV}_{\mathrm{FF}, \mathrm{PJ}}=$ net calorific value (NCV) of fossil fuel used in the Project turbine during year y (TJ/tonne of fuel).

$\eta_{\mathrm{BL}, \mathrm{y}}=$ energy efficiency of the turbine without retrofitting estimated using the latest version of approved "tool to determine the baseline efficiency of thermal or electric energy generation systems," determined the efficiency based on measurements and used a conservative value, based on performance tests before the implementing the project following national/international standards, at discrete loads within the operating range or over the entire rated capacity, $\mathrm{FC}_{\mathrm{PJ}, \mathrm{y}}=$ Actual fuel consumption by project in year " $\mathrm{y}$ " (tonne of fuel), $\mathrm{HI}_{\mathrm{PJ}, \mathrm{y}}=$ Heat input to the steam turbine in year " $y$ " (TJ). In case of multicylinder steam turbines, this is the sum of the heat input at the inlet of first stage and the heat inputs in the re-heaters of steam between various cylinders (e.g., high-pressure, medium pressure, and lowpressure cylinders).

3.1.2. Calculate the Project Emissions. The $\mathrm{CO}_{2}$ emissions from fossil fuel consumption in the project $\left(\mathrm{PE}_{\mathrm{y}}\right)$ should be calculated using the latest approved version of the "tool to calculate project or leakage $\mathrm{CO}_{2}$ emissions from fossil fuel combustion," where the process $j$ in the tool corresponds to the combustion of fossil fuels in the project for electricity generation in the project power plants [11]:

$$
\mathrm{PE}_{\mathrm{FC}, \mathrm{j}, \mathrm{y}}=\sum_{\mathrm{i}} \mathrm{FC}_{\mathrm{i}, \mathrm{j}, \mathrm{y}} \times \mathrm{COEF}_{\mathrm{i}, \mathrm{y}},
$$

where $\mathrm{PE}_{\mathrm{FC}, \mathrm{jy}}=$ are the $\mathrm{CO}_{2}$ emissions from fossil fuel combustion in process $\mathrm{j}$ during the year $\mathrm{y}, \mathrm{FC}_{\mathrm{i}, \mathrm{j}, \mathrm{y}}=$ is the quantity of fuel type i combusted in process $j$ during the year $\mathrm{y}$ (mass or volume unit/yr), $\mathrm{COEF}_{\mathrm{i}, \mathrm{y}}=$ is the $\mathrm{CO}_{2}$ emission coefficient of fuel type $\mathrm{i}$ in year y $\left(\mathrm{tCO}_{2} /\right.$ mass or volume unit), $i=$ are the fuel types combusted in process $j$ during the year $\mathrm{y}$.

The $\mathrm{CO}_{2}$ emission coefficient $\mathrm{COEF}_{\mathrm{i}, \mathrm{y}}$ can be calculated using one of two options proposed in the "tool to calculate project or leakage $\mathrm{CO}_{2}$ emissions from fossil fuel combustion".Depending on the availability of data on the fossil fuel type $\mathrm{i}$, the $\mathrm{CO}_{2}$ emission coefficient $\mathrm{COEF}_{\mathrm{i}, \mathrm{y}}$ is calculated based on net calorific value and $\mathrm{CO}_{2}$ emission factor of the fuel type i:

$$
\mathrm{COEF}_{\mathrm{i}, \mathrm{y}}=\mathrm{NCV}_{\mathrm{i}, \mathrm{y}} \times \mathrm{EF}_{\mathrm{CO}_{2}, \mathrm{i}, \mathrm{y}}
$$

where $\mathrm{COEF}_{\mathrm{i}, \mathrm{y}}=$ is the $\mathrm{CO}_{2}$ emission coefficient of fuel type $\mathrm{i}$ in year $\mathrm{y}\left(\mathrm{tCO}_{2} /\right.$ mass or volume unit), $\mathrm{NCV}_{\mathrm{i}, \mathrm{y}}=$ is the weighted average net calorific value of the fuel type $i$ in year $y$ ( $\mathrm{GJ} /$ mass or volume unit). $\mathrm{EF}_{\mathrm{CO}_{2}, \mathrm{i}, \mathrm{y}}=$ is the weighted average $\mathrm{CO}_{2}$ emission factor of fuel type $\mathrm{i}$ in year y $\left(\mathrm{tCO}_{2} / \mathrm{GJ}\right), \mathrm{i}=$ are the fuel types combusted in process $\mathrm{j}$ during the year $\mathrm{y}$.

3.1.3. Calculate the Emission Reductions. (1) Emission reductions are calculated as follows:

$$
\mathrm{ER}_{\mathrm{y}}=\mathrm{BE}_{\mathrm{y}}-\mathrm{PE}_{\mathrm{y}},
$$

where $\mathrm{ER}_{\mathrm{y}}=$ emissions reductions in year y $\left(\mathrm{tCO}_{2} \mathrm{e} / \mathrm{yr}\right)$, $\mathrm{BE}_{\mathrm{y}}=$ baseline emissions in year $\mathrm{y}\left(t \mathrm{CO}_{2} \mathrm{e} / \mathrm{yr}\right), \mathrm{PE}_{\mathrm{y}}=$ project emissions in year y $\left(\mathrm{tCO}_{2} \mathrm{e} / \mathrm{yr}\right)$.

(2) Data and parameters which are available at validation. Because the regional specific value is not available, the Intergovernmental Panel on Climate Change (IPCC) default value of the $\mathrm{CO}_{2}$ emission factor of coal was selected. Choose the $\mathrm{CO}_{2}$ emission factor corresponding to the applicable fuel type. IPCC default values may be used. $\mathrm{CO}_{2}$ emission factor of the fossil fuel used in the Project turbine prior to the 
TABLE 2: The key parameters of the project.

\begin{tabular}{|c|c|c|c|}
\hline Item & Value & Unit & Data source \\
\hline Electricity supplied to the grid in year y $\left(\mathrm{EG}_{\mathrm{PJ}, \mathrm{y}}\right)$ & $2,632,000$ & MWh & Feasibility study report of the project (FSR) \\
\hline Standard coal consumption after retrofit & 322.5956 & $\mathrm{~kg} / \mathrm{MWh}$ & Efficiency test report \\
\hline Net calorific value of standard coal & 29,306 & $\mathrm{MJ} /$ ton & Efficiency test report \\
\hline Net calorific value of fossil coal & 23,026 & $\mathrm{MJ} /$ ton & Calculated \\
\hline Annual consumption of fossil coal & $1,080,643.24$ & ton & Calculated \\
\hline Average net heat consumption of turbine after retrofit & 8738.92 & $\mathrm{~kJ} / \mathrm{kWh}$ & Efficiency test report \\
\hline
\end{tabular}

implementation the Project $\left(\mathrm{EF}_{\mathrm{FF}, \mathrm{BL}}\right)=89.5 \mathrm{tCO}_{2} / \mathrm{TJ}$ of fuel [12].

Use the latest version of approved "tool to determine the baseline efficiency of thermal or electric energy generation systems." Depending upon the option selected from the latest version of approved "tool to determine the baseline efficiency of thermal or electric energy generation systems." Energy efficiency of the turbine without retrofitting in a year $\mathrm{y}\left(\eta_{\mathrm{BL}, \mathrm{y}}\right)=39.553 \%$ (from Efficiency Test Report of the PAT prior to the retrofit).

(3) Ex-ante calculation of emission reductions. In order to estimate the emission reductions generated by the project, the following assumptions are brought into account.

(4) Calculate the baseline emissions:

$$
\begin{aligned}
& \mathrm{EF}_{\mathrm{BL}, \mathrm{y}}= \frac{3.6}{1000} \times \frac{\mathrm{EF}_{\mathrm{FF}, \mathrm{BL}} \times \mathrm{FC}_{\mathrm{PJ}, \mathrm{y}} \times \mathrm{NCV}_{\mathrm{FF}, \mathrm{PJ}}}{\eta_{\mathrm{BL}, \mathrm{y}} \times \mathrm{HI}_{\mathrm{PJ}, \mathrm{y}}} \\
&= \frac{3.6}{1000} \\
& \times \frac{89.5 \times(322.5956 \times 2,632,000) \times 0.029306}{0.39553 \times 2,632,000 \times 8738.92} \\
&= \frac{0.88126 t \mathrm{CO}_{2} e}{\mathrm{MMh}}, \\
& \mathrm{BE}_{\mathrm{y}}=\mathrm{EG}_{\mathrm{PJ}, \mathrm{y}} * \mathrm{EF}_{\mathrm{BL}, \mathrm{y}}=2,632,000 * 0.88126 \\
&=2,319,482 \mathrm{tCO}_{2} e .
\end{aligned}
$$

(5) Calculate the project emissions:

$$
\begin{aligned}
\mathrm{PE}_{\mathrm{y}}= & \mathrm{FC}_{\text {coal,y }} \times \mathrm{NCV}_{\text {coal,y }} \times \mathrm{EF}_{\mathrm{CO} 2, \text { coal,y }} \\
= & 1,080,643.24 \text { ton } \times 0.023026 \mathrm{TJ} / \text { ton } \\
& \times 89.5 \mathrm{tCO}_{2} e / \mathrm{TJ} \\
= & 2,227,019 \mathrm{tCO}_{2} e .
\end{aligned}
$$

(6) Calculate the emission reductions:

$$
\begin{aligned}
\mathrm{ER}_{\mathrm{y}} & =\mathrm{BE}_{\mathrm{y}}-\mathrm{PE}_{\mathrm{y}}=2,319,482-2,227,019 \\
& =92,463 \mathrm{tCO}_{2} e .
\end{aligned}
$$

3.1.4. Summary of the Ex-Ante Estimation of Emission Reductions. It is expected that the project activities will generate emission reductions within the power grid for about 92,463
$\mathrm{tCO}_{2}$ e per annum over an 8-year fixed crediting period from $01 / 01 / 2012$ to $31 / 12 / 2019$. And the total emission reductions will come to $739,704 \mathrm{tCO}_{2} e$.

\subsection{Investment Analysis}

3.2.1. Determine the Suitable Financial Indicator for the Project Type. Financial indicator of internal rate of return (IRR) is the most suitable for such power retrofit project and decision making context. According to Trial Implementation Methods for Economic Assessment of technology retrofit Project in Power Engineering, the benchmark of IRR of power retrofit project is set at $8 \%$ [13]. The financial attractiveness of this project will be determined by comparing the IRR after tax (without Certified Emission Reductions (CERs)) with its benchmark applied in power retrofit project of China power industry, which is a standard recommended by the industry experts and is widely used at present in China. If the IRR after tax (without CERs) is less than $8 \%$, the project is considered not being financially attractive in the absence of CDM revenues, and is therefore considered to be additional.

\subsubsection{Calculation and Comparison of Financial Indicators.} The key parameters of the project are showed in Tables 2 and 3.

The financial analysis results are shown in Table 4. As shown in this table, without carbon credits, the IRR is $-0.41 \%$, which is much lower than the benchmark rate of $8 \%$. This therefore indicates that in comparison to other alternative investments, the project without carbon credits is not financially attractive to a rational investor.

3.2.3. Sensitivity Analysis. The sensitivity analysis is conducted to check whether, under reasonable variations of the sensitive factors in the critical assumptions, the results from the analysis remain unaltered. After overall checking of the IRR calculation sheet, five factors have been selected for the sensitivity analysis, which are the total investment, annual operation hours, electricity tariff, standard coal price, and the decrease of standard coal consumption.

Assuming the five factors within a fluctuation range from $-20 \%$ to $20 \%$, the IRR (after tax) of the project (without income from selling CERs) varies to a different extent, as shown in Table 5.

As shown in the sensitivity analysis, even the varying range of the uncertain factors reaches $\pm 20 \%$, the IRR (after tax) could not reach the benchmark. The conclusion that the 
TABLE 3: The key parameters of the proposed project.

\begin{tabular}{|c|c|c|c|}
\hline Item & Value & Unit & Data source \\
\hline Rated continuous power & 500 & MW & FSR \\
\hline Total investment & $100,000,000$ & RMB & FSR \\
\hline Equity proportion & 100 & $\%$ & FSR \\
\hline Incremental annual power generation & 0 & MWh & FSR \\
\hline Profit loss due to the retrofitting & $24,730,000$ & $\mathrm{RMB}$ & FSR \\
\hline Annual operation hours & 5600 & $\mathrm{~h}$ & FSR \\
\hline Power consumption rate (for self-use) & 6 & $\%$ & FSR \\
\hline $\begin{array}{l}\text { Standard coal consumption for power generation before retrofit } \\
\text { (designed in FSR) }\end{array}$ & 316 & $\mathrm{~g} / \mathrm{KWh}$ & FSR \\
\hline Decrease of standard coal consumption after retrofit (designed in FSR) & 13 & $\mathrm{~g} / \mathrm{KWh}$ & FSR, P51 \\
\hline Standard coal price (without VAT) & 389 & $\mathrm{RMB} /$ ton & FSR \\
\hline Electricity tariff (without VAT) & 341.2 & $\mathrm{RMB} / \mathrm{MWh}$ & FSR \\
\hline New added $O$ and $M$ cost & $-11,675,000$ & RMB/year & FSR \\
\hline Of which fuel cost saving due to retrofit & $-14,175,000$ & $\mathrm{RMB} /$ year & FSR \\
\hline New added repair cost & $2,500,000$ & RMB/year & FSR \\
\hline Income tax & 25 & $\%$ & FSR \\
\hline Value added tax (VAT) & 17 & $\%$ & FSR \\
\hline Town building maintenance tax & 7 (of VAT) & $\%$ & FSR \\
\hline Surcharge for education & 3 (of VAT) & $\%$ & FSR \\
\hline Project operating period & 11 & Years & FSR \\
\hline Rate of residual value of the fixed assets & 3 (out of total investment) & $\%$ & FSR \\
\hline Depreciation period & 11 & Years & FSR \\
\hline Amount of CERs & 92,463 & $\mathrm{tCO}_{2} \mathrm{e} /$ year & ER calculation sheet \\
\hline
\end{tabular}

TABLE 4: The financial indicators of the project.

\begin{tabular}{lc}
\hline Financial indicators & Rate \\
\hline IRR (after tax) without CERs & $-0.41 \%$ \\
Benchmark & $8 \%$ \\
IRR with CERs & $8.27 \%$ \\
\hline
\end{tabular}

project is definitely not financially attractive would not be influenced.

As above, the internal rate of return (IRR) of the project is only $-0.41 \%$ without the revenue of carbon credits for example, CERs, which is much lower than the benchmark value of $8 \%$. In addition, only when the unit price of carbon credit comes to $125 \mathrm{CNY} / \mathrm{tCO}_{2}$, the IRR could reach the benchmark and become financially feasible. Therefore the GHG emission reduction cost of such retrofit project is 125 $\mathrm{CNY} / \mathrm{tCO}_{2}$.

\subsection{Design of Incentive Mechanism}

3.3.1. Incentive from Carbon Tax. Carbon tax is a Pigovian tax levied on the carbon content of fuels [14], which is a form of carbon pricing. Carbon is present in every hydrocarbon fuel (coal, petroleum, and natural gas) and is released as $\mathrm{CO}_{2}$, when they are burnt [15].
In this case study, it is assumed that government levies the carbon tax on coal consumption in the power sector. It means that the carbon tax will be a part of the fuel cost in operating the power plant, being of the same effect of raising the price of coal. According to the sensitive analysis, an effective carbon tax needs to increase the price of coal by $243 \mathrm{CNY} / \mathrm{tce}$, so as to make the project financially feasible. Then the cost of carbon tax should be $90 \mathrm{CNY} / \mathrm{tCO}_{2}$ (1tce leads to GHG emission of $2.77 \mathrm{tCO}_{2}$ ).

3.3.2. Incentive from Carbon Market (Credit Trading). Emissions trading or cap-and-trade is a market-based approach used to control pollution by providing economic incentives for achieving reductions in the emissions of pollutants. For GHG the largest is the European Union Emission Trading Scheme (ETS), whose purpose is to avoid dangerous climate change [16]. In the carbon market created by ETS, GHG emission reduction credits are a kind of eligible unit, generated from the project that is implemented by entity outside the ETS. As analyzed above, the price of carbon credits in the market for example, CERs must be not less than $125 \mathrm{CNY} / \mathrm{tCO}_{2}$ to make the project financially attractive.

3.3.3. Incentives Combined with Encouraging Dispatch Plan. Since the electricity tariff is determined by the government in China, which is fixed unless the new tariff policy approved by the government, most of the coal fuel power plants resist 
TABLE 5: The sensitivity analysis of the project within a fluctuation range from $-20 \%$ to $20 \%$.

\begin{tabular}{|c|c|c|c|c|c|}
\hline Fluctuation range & $-20 \%$ & $-10 \%$ & 0 & $10 \%$ & $20 \%$ \\
\hline Total investment & $2.34 \%$ & $0.87 \%$ & $-0.41 \%$ & $-1.55 \%$ & $-2.57 \%$ \\
\hline Annual operation hours & $-3.64 \%$ & $-1.98 \%$ & $-0.41 \%$ & $1.08 \%$ & $2.50 \%$ \\
\hline Electricity tariff & $-0.41 \%$ & $-0.41 \%$ & $-0.41 \%$ & $-0.41 \%$ & $-0.41 \%$ \\
\hline Standard coal price & $-3.64 \%$ & $-1.98 \%$ & $-0.41 \%$ & $1.08 \%$ & $2.50 \%$ \\
\hline Decrease of standard coal consumption & $-3.64 \%$ & $-1.98 \%$ & $-0.41 \%$ & $1.08 \%$ & $2.50 \%$ \\
\hline
\end{tabular}

TABLE 6: The necessary cost of carbon tax and credit price with/without encouraging dispatch plan.

\begin{tabular}{lcc}
\hline Dispatch plan & Necessary cost of Carbon tax & Necessary cost of credit price \\
\hline The dispatch electricity generation does not change & $90 \mathrm{CNY} / \mathrm{tCO}_{2}$ & $125 \mathrm{CNY} / \mathrm{tCO} 2$ \\
Dispatched electricity generation increased by $20 \%$ & $50 \mathrm{CNY} / \mathrm{tCO}_{2}$ & $85 \mathrm{CNY} / \mathrm{tCO}{ }_{2}$ \\
\hline
\end{tabular}

carbon tax in practice. A very high cost of carbon tax is not very likely to occur in China. On the other hand, given the experience of the EU ETS, the credit price is of high volatility in the market [17]. Thus, there is always uncertainty about the credit price to make the investment decisions of this kind of retrofit. To mitigate the shortage of carbon tax and carbon market, the encouraging dispatch plan is expected to enhance the effect from above mechanisms.

Given the sensitivity analysis, the annual operation hours of the PAT are a very crucial factor to the IRR. The annual operation hours of a power plant are normally determined by power dispatch arrangement of grid company. In this section, the effect of encouraging dispatch plan is an analysis together with carbon tax and credit price in an ETS. Clearly, the more annual operation hours of the PAT, the higher IRR appears in the Project (Table 6). Thus, the necessary cost of either carbon tax and credit cost in ETS will decrease by incorporating with such encourage to dispatch plan.

\section{Conclusions}

This study presented the emission reductions of an ordinary thermal power plant after a steam turbine retrofit project with an incentive mechanism of carbon tax and carbon market (ETS). In particular, the most cost-efficient method is the combination of this mechanism made by central authorities with encouraging dispatch plan by grid company. The results presented within this paper indicate that the project will make a good demonstration for the other low efficiency thermal power plants in China.

\section{Acknowledgments}

This work was financially supported by the National Natural Science Foundation of China (nos. 50908219 and 51209003), the Major Special Technological Program of Water Pollution Control and Management (no. 2010ZX07320-002), and Central Public-interest Scientific Institution Basal Research Fund (no. 0032012013).

\section{References}

[1] T. M. L. Wigley, R. Richels, and J. A. Edmonds, "Economic and environmental choices in the stabilization of atmospheric $\mathrm{CO}_{2}$ concentrations," Nature, vol. 379, no. 6562, pp. 240-243, 1996.

[2] G. J. Boer, G. Flato, and D. Ramsden, "A transient climate change simulation with greenhouse gas and aerosol forcing: projected climate to the twenty-first century," Climate Dynamics, vol. 16, no. 6, pp. 427-450, 2000.

[3] Z. Z. Hu, S. Yang, and R. Wu, "Long-term climate variations in China and global warming signals," Journal of Geophysical Research D, vol. 108, no. 10, pp. 4614-4626, 2003.

[4] B. Bai, X. Li, Y. Liu, and Y. Zhang, "Preliminary study on $\mathrm{CO}_{2}$ industrial point sources and their distribution in China," Chinese Journal of Rock Mechanics and Engineering, vol. 25, no. 2, pp. 2918-2923, 2006.

[5] The Climate Group, "Delivering low carbon growth: a guide to China's 12th Five Year Plan,” 2011.

[6] M. I. Hoffert, K. Caldeira, G. Benford et al., "Engineering: advanced technology paths to global climate stability: energy for a greenhouse planet," Science, vol. 298, no. 5595, pp. 981987, 2002.

[7] D. Mollicone, F. Achard, S. Federici et al., "An incentive mechanism for reducing emissions from conversion of intact and non-intact forests," Climatic Change, vol. 83, no. 4, pp. 477-493, 2007.

[8] UNFCCC/CCNUCC, "Approved baseline and monitoring methodology AM0062: energy efficiency improvements of a power plant through retrofitting turbines," AM0062/Version 02, Sectoral Scope: 01, EB 55.

[9] UNFCCC/CCNUCC, "Methodological tool "combined tool to identify the baseline scenario and demonstrate additionality" (Version 04.0.0),” EB 66, Report Annex 48.

[10] UNFCCC/CCNUCC, "Methodological tool "tool to calculate the emission factor for an electricity system" (Version 02.2.1)," EB 63, Report Annex 19.

[11] UNFCCC/CCNUCC, "Methodological tool "tool to calculate project or leakage $\mathrm{CO}_{2}$ emissions from fossil fuel combustion" (Version 02)," EB 41, Report Annex 11.

[12] UNFCCC/CCNUCC, "Methodological tool "tool to calculate the emission factor for an electricity system" (Version 02.2.1)," EB 63, Report Annex 19.

[13] State Power Corporation, "Trial Implementation Methods for Economic Assessment of technology retrofit Project in Power Engineering," 2003. 
[14] P. Hoeller and M. Wallin, "Energy prices, taxes and carbon dioxide emissions," OECD Economics and Statistics Department Working Papers 106, Organisation for Economic Cooperation and Development, Paris, Farnce, 1991.

[15] A. Staudt, Understanding and Responding to Global Climate Change: Highlights of National Academies Reports, National Academy of Sciences, 2008.

[16] EU Emissions Trading System (EU ETS), "UK Department of Energy and Climate Change," 2009.

[17] R. S. J. Tol, "The marginal damage costs of carbon dioxide emissions: an assessment of the uncertainties," Energy Policy, vol. 33, no. 16, pp. 2064-2074, 2005. 

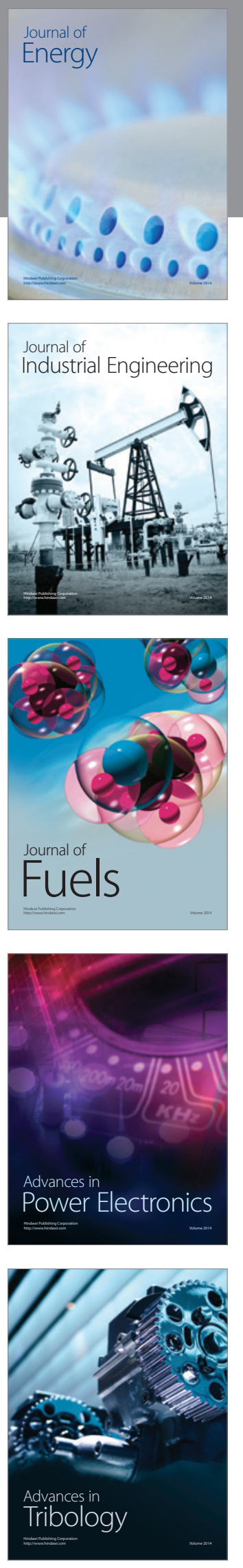
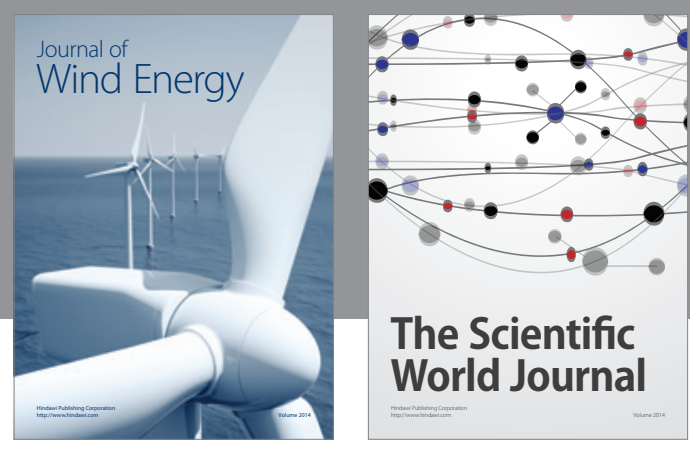

The Scientific World Journal

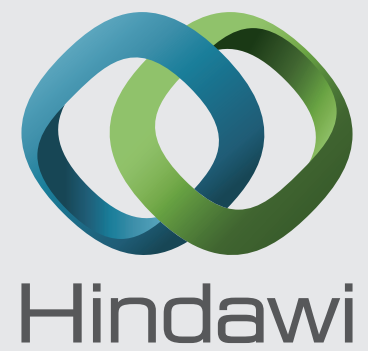

Submit your manuscripts at http://www.hindawi.com
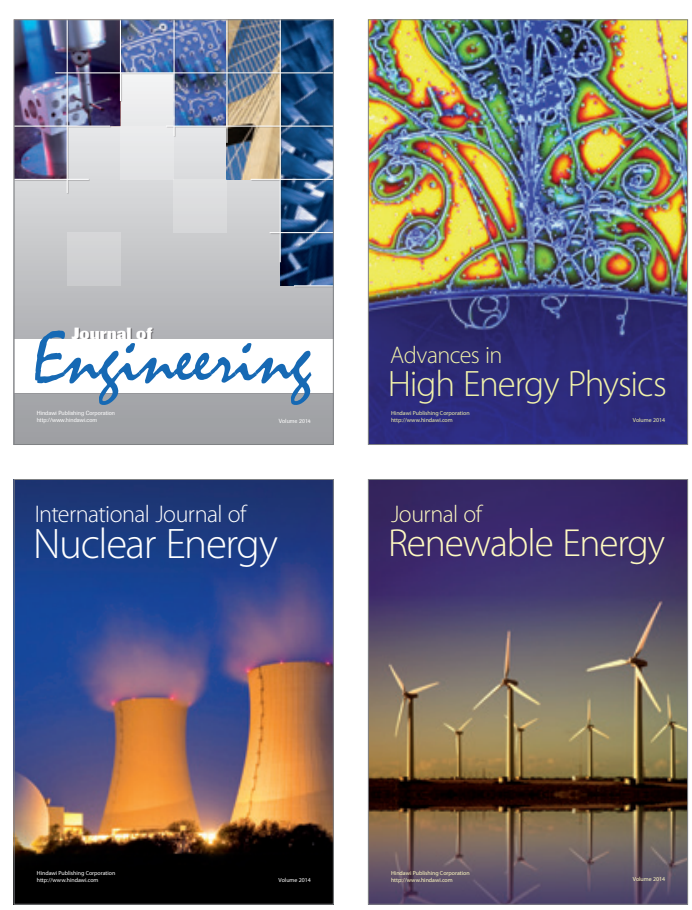

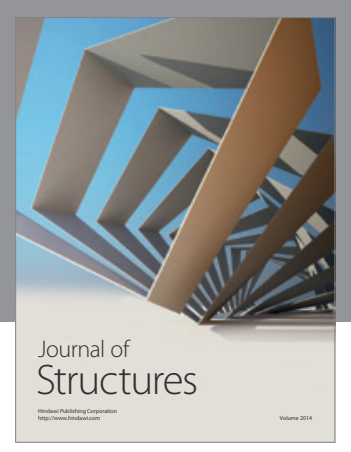

Rotating
Mechinery
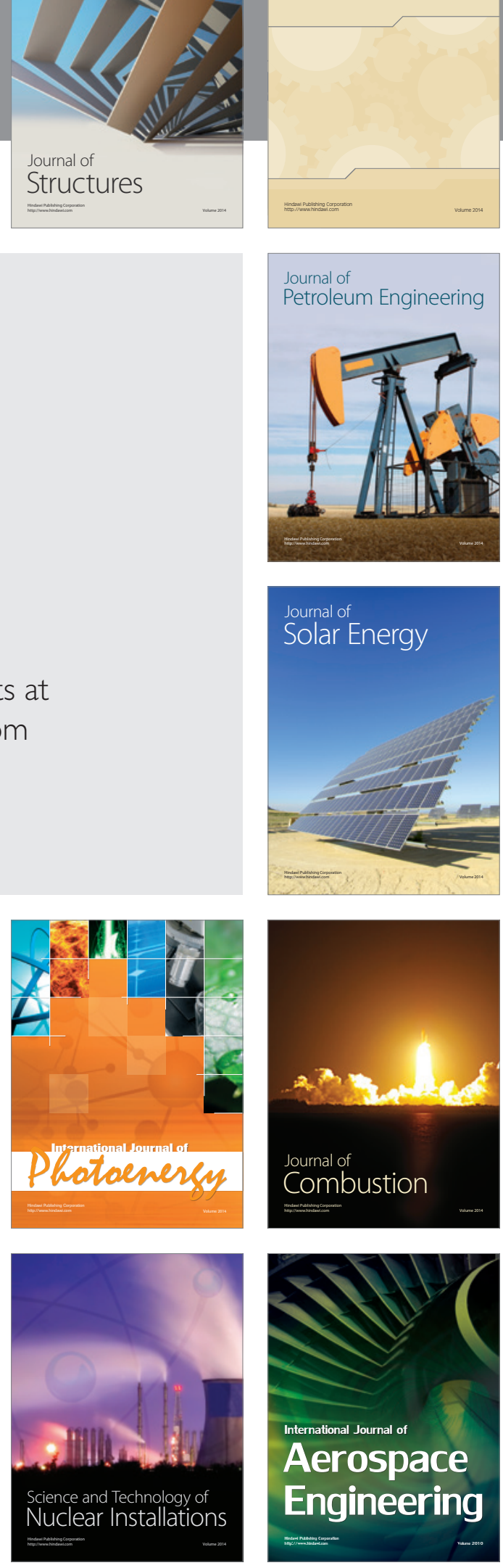